\title{
Te Umutaoroa, Patuheuheu and Ngāti Haka: Towards a Prophetic Model for Unity and Transformation
}

\section{Introduction}

This article explores the emergence of a prophecy called Te Umutaoroa (earth oven of long cooking), given to Patuheuheu and Ngāti Haka by Te Kooti Arikirangi - a nineteenth century Māori leader whom the government wanted to eliminate. This was a discourse uttered by Te Kooti in 1886 and promised the restoration of all that was taken away from Patuheuheu and Ngāti Haka in the mid 1880s and beyond. This article asserts that Te Kooti was both a prophet and transformational leader. This work is the beginning of a framework for hapu development based on the eight parts or promises contained within Te Kooti's Te Umutaoroa prophecy. The purpose of this work is to scope out the 'bones' of a framework which aims for complete unity between Patuheuheu and Ngāti Haka, and through the united efforts of both hapū, development and positive transformation in the various contexts of the Waiohau community.

Patuheuheu and Ngāti Haka are two hapū from the Tūhoe tribe, who have at least for the last two or three generations, argued about the authenticity of the two different hapu identities. Indeed, the author's own personal research journey, being of Patuheuheu descent himself, has been peppered with internal struggle and negotiation between these two identities in both historical and contemporary contexts. Elsdon Best (1925) claims that “...three generations ago" (p. 221) when Whare, Ngai Tūhoe and Ngāti Porou descent. 
some members of Ngāti Haka were slain by Ngāti Awa in a thicket, the clan name was changed to Patuheuheu - literally a 'thicket slaying'. Indeed, the identity of Patuheuheu is found more predominantly throughout the historical archives, while Angela Ballara's (1998) statement that Patuheuheu was amongst the more important Tūhoe hapu of the nineteenth century, is significant here. Other evidence suggests that Patuheuheu has been around a lot longer than Best implies. For example, the author's third-great-grandfather, Mēhaka Tokopounamu gave evidence in court in 1884, stating that Patuheuheu lived at Matahina (near modern day Waiohau) during the dynasty of Tangiharuru, a principle ancestor of Ngāti Manawa and Mēhaka's eigth-great-grandfather. This statement opposes Best's claim that Patuheuheu emerged out of Ngāti Haka within the time period he suggests. The author descends from two Patuheuheu families: Nātana and Rikiriki. These families maintain their unique Patuheuheutanga and thus do not identify as Ngāti Haka. Certainly, the author's great-grandfather, Hāpurona Maki Nātana, did not hesitate to 'slice down' anyone who opposed Patuheuheu's authority and mana whenua. So it is within this context at the crossroads of whakapapa, history and debate that the author has had to conduct this research.

Indigenous knowledges are interpretive (Cajete, 1999; Deloria, 2002; Henderson, 2000; Little Bear, 2000) and so can be aligned with constructivist hypotheses (Kovach, 2009). Likewise, Māori knowledge is interpretive, and by extension, Patuheuheu and Ngāti Haka knowledge can also be subject to multiple interpretations. With this in mind, it is the author's view that Patuheuheu and Ngāti haka are not homogenous identities, meaning that in this context a constructivist approach to work around Patuheuheu and Ngāti Haka identities is feasible. Since a constructivist approach advocates that there are multiple ways of seeing the world (Eketone, 2008), it allows Patuheuheu and Ngāti Haka narratives and histories, however conflicting at points, to exist in parallel with 
each other, rather than in complete opposition - which would inhibit hapu development. In this way, this work promotes inclusivity despite historical and contemporary debates around the authenticity of Patuheuheu and Ngāti Haka, their whakapapa and mana whenua. This work also acknowledges the fact that Patuheuheu and Ngāti Haka are essentially seen as, or operate as, one people (Ballara, 1998; Best, 1925; Binney, 2001a, 2002, 2009a; Pouwhare, 2004).

In the 1870s Patuheuheu and Ngāti Haka were seen as rebels by the government because of their relationship with $\mathrm{Te}$ Kooti. Consequently, Patuheuheu and Ngāti Haka were forced by the government to relocate from their lands in the Rangitaiki Valley to Te Putere, near Matatā in the Eastern Bay of Plenty, where they were detained in what has been referred to by the historian Judith Binney $(2002,2003,2009$ a) as a 'concentration camp'. However, in 1872 they were allowed to return home to the Rangitaiki Valley and re-establish their lives at Te Houhi. From the mid 1880s however, the lives of Patuheuheu and Ngāti Haka were to change dramatically.

In 1886 Harry Burt, a prominent Pākeha living in the Te Houhi community, defrauded Patuheuheu and Ngāti Haka's land away using the land court system. This event became known in New Zealand legal history as the 'Waiohau Fraud'. In time the land came to be owned by James Grant, who evicted Patuheuheu and Ngāti Haka in 1907. Thus Patuheuheu and Ngāti Haka were forced to relocate to their less fertile lands at Waiohau - between Galatea and Te Teko - which became their 'new' home base. To add insult to injury, the government confiscated most of their remaining lands at Matahina at the same time they were being evicted from Te Houhi, to pay for a land survey that Patuheuheu and Ngāti Haka did not ask for (Binney, 2001a, 2002; Nikora, 2004b; Paul, 1995; Porima, 1994; Pouwhare, 2004; Ranui, 2004). 


\section{Ngā mauri e waru: eight principles for transformation}

In the nineteenth century, Te Kooti was conscious and aware of the oppression that Patuheuheu and Ngāti Haka, like all Māori faced, and thus he engaged in ideological and physical resistance, opposing the government and warning his followers against land sales (Binney, 1995, 2001a, 2009a). Te Kooti gave a revelation of hope which emerged first as a dream, which was then envisaged by Patuheuheu and Ngāti Haka as a projection of future outcomes: a vision which alleviated some of the heartache of land loss and inspired the people with optimism for better things to come. Hence, his Te Umutaoroa narrative offered a utopian vision with the potential to be re-imagined and re-imaged as a blueprint for hapu transformation and development. It was and is a discourse which delivered hope to the hope-less, promising Patuheuheu and Ngāti Haka the return of their lost lands and resources, and according to some narratives, the discovery or generation of other resources such as diamonds, gold, oil and minerals. This legacy continues today amongst his contemporary followers in the Waiohau valley.

According to the Reverend Hieke Tupe (Doherty, 1995; Binney, 2001a, 2009a) and Robert (Boy) Biddle (Binney, 2001a, 2007a 2009a), Te Kooti had a dream in 1886 that the Rangitaiki valley was blanketed in a thick fog; the physical location where Te Kooti had his dream was named by him, 'Te Umutaoroa'. Robert Biddle states:

Up where the Aniwhenua dam is, now, it used to be dry land before... Te Kooti was there, he slept at this particular pā [Te Houhi], and where he did sleep, he said to them in the morning, 'I had a dream last night: the valley of the Rangitaiki here was just dense fog...' He said, 'I couldn't see through this fog, so the place where I slept, it will be known as Te Umutaoroa'. That's a hangi - it would be perpetually in that form until this person came and uncovered it (Binney, 2007a, p. 153). 
Within this hangi pit Te Kooti placed eight stones to be uncovered by a future leader, his 'child' or 'son', to restore all that the people of Te Houhi had lost (Doherty, 1995; Binney, 2001a). The Reverend Hieke Tupe gave the following meanings of the mauri of Te Umutaoroaa:

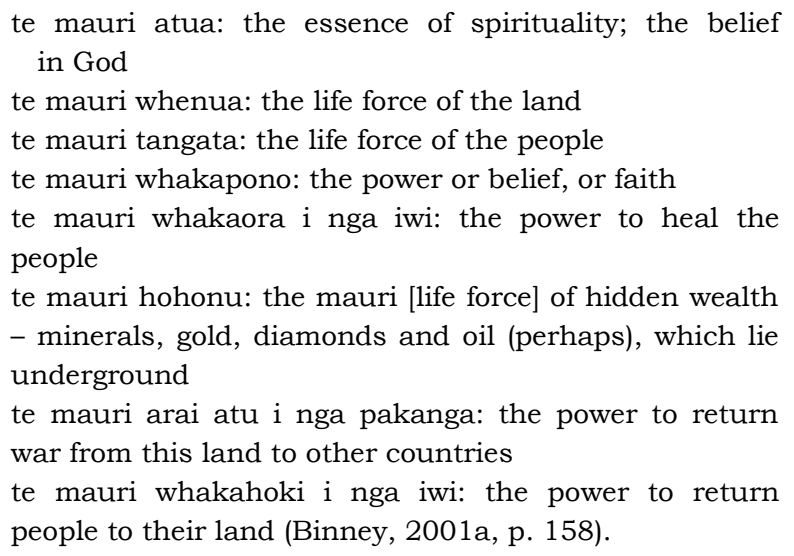

The uncovering of these eight talismans guarantees for the people of Te Houhi, spiritual and physical renewal; regeneration; reuniting of people and land; and economic security (Binney, 2001a). Here Te Kooti was able to convert the tragic story of Te Houhi's land loss into a quest for a new future to be uncovered by revealing the mauri or life forces contained within the symbolic and mystical cooking pit of Te Umutaoroa.

Te Kooti claimed that the 'earth oven of long cooking' would only contain "'raw' and putrefying food, for him [Burt]: the greatest insult possible from host to guest, and the marker of the end of all reciprocity" (Binney, 2001a, p. 150, 2007a). For the dispossessed people of Te Houhi, on the other hand, the numinous hāngi would one day provide the 'cooked' 'sustenance of life' (Binney, 2001a, 2007a), and although the 
original site where Te Kooti claimed to have left the stones of Te Umutaoroa has been covered in water by the Aniwhenua dam, Patuheuheu and Ngāti Haka continue to show their faith in Te Kooti's words. It is believed that Te Umutaoroa is symbolic of all that was lost and all that will be restored (Pouwhare, 2004), and that it "...will never be washed away: that is the promise for our generation to know" (Pouwhare, 2000, cited in Binney, 2001a, p. 159). In 1892 Te Kooti clarified his vision:

Te kupu ki te Umutaoroa - Te Houhi

Ka taona e ahau tenei hangi ma taku tamaiti e hura

Tenei mea te hangi, ko nga kai o roto hei ora mo te tangata

The word concerning Te Umutaoroa - Te Houhi

I am preparing this hängi (earth oven) for my child to unearth.

The food inside this hāngi will be for the salvation of the people (cited in Binney, 2007a, p. 153).

Te Kooti's vision shows he believed that Te Umutaoroa would bring salvation to the people, while the author claims, that the contents therein also have the potential to unite and transform the people of Waiohau through a kind of 'ingestive praxis' - to be expanded upon in future research - where participants consume the 'food' from the earth oven and are changed positively because of the 'salvation' inherent in it. This has been demonstrated in part by the political action engaged in by Patuheuheu and Ngāti Haka - following dissatisfaction with the Treaty settlement process and Tūhoe's negotiation strategy - through the formation of the Te Umutaoroa social and political movement since 2008 (see Rangiwai, 2010). Furthermore, the eight mauri have through the years been subjected to interpretation, and this will continue through the generations until the prophecy is fulfilled: 
...Te Kooti's quest-narrative has acquired an autonomous life. It is no longer tied [exclusively] to its origins, a land fraud carried out by a trickster who had once been Te Kooti's friend. It has been transformed to possess vastly extended meanings... (Binney, 2007a, p. 154).

In this way, Te Umutaoroa continues to evoke multiple and interpretive meanings for Patuheuheu and Ngāti Haka, adaptable for various contexts. Within the context of this article, Te Umutaoroa is a vision or theory with the potential to neutralise the historical injustices inflicted on Patuheuheu and Ngāti Haka. However, Te Kooti's vision requires more than theorising and prophesying. It necessitates a course of continued action, requiring both theory and practice by 'followers' who have internalised the discourse, transporting Te Umutaoroa from the nineteenth century to the 'here and now'. The Te Umutaoroa social and political movement, is but one such example of action underpinned by 'visionary theory', while the continued hope of Patuheuheu and Ngāti Haka for the return of their lands through waiata, moteatea, karakia, whaikorero, kapa haka, hauora and other cultural practices, are yet other examples.

\section{Te Kooti as a transformational prophet-leader}

$\mathrm{Te}$ Kooti's prophetic millenarian legacy emerged as a response to colonisation and displacement (Binney, Chaplain, \& Wallace, 1979), a common occurrence amongst oppressed Indigenous peoples (Adas, 1979), such as the prophetic resistance movements which emerged amongst some Native American clans in the nineteenth century (Johnson, 1996; Overholt, 1974). Like Moses and other Old Testament prophets, Te Kooti believed himself to be 'called by God' to save a people dispossessed of their homeland (Binney, 1988, 1997, 2008; Elsmore, 1999; Sinclair, 2002). His claim was that the spirit of God told him to "Rise! Come forth! You are 
spared to be made well [after sickness with tuberculosis], to be the founder of a new church and religion, to be the salvation of the Maori people and to release them from bondage" (Ross, 1966, p. 30).

According to Stone and Patterson (2005), Egyptian rulers, Greek heroes and ancient biblical prophets all had one attribute in common: leadership. A prophet is generally thought of as a messenger of God, the Gods, and/or ancestors (Adrahtas, 2007; Kaplan, 1908; Sheppard \& Herbrechtsmeier, 2005). As well as being messengers, predictors, preachers, teachers, political leaders, healers, miracle workers, and poets, prophets are also described as revolutionary leaders who make great changes (Kaplan, 1908). Prophets give words of inspiration and prediction which become hierophanous events, where the sacred is manifested in the world as 'modes of praxis', signifying the unity of 'identity and transformation' (Adrahtas, 2007). As such, prophets can be seen as 'transformational leaders' who motivate their followers to engage in making the vision or 'dream come true'.

Transformational leadership is concerned with and centred on, the collective welfare of groups and communities (Shields, 2003), while transformative leadership concentrates on social justice in ways which create new potentials for transformation and development (Astin \& Astin, 2002). In this article, the term 'transformational' will be used to denote both transformative and transformational approaches to leadership. According to Burns (1978) transformational leaders ask followers to rise above their own interests for the sake of collective ones, and to focus on the development and implementation of long term 'future' goals and ambitions, thus working towards transformation (Gardner \& Avolio, 1998, cited in Punj \& Krishnan, 2006; Punj \& Krishnan, 2006; Shamir, House \& Arthur, 1993).

Burns (1978) claims that Mahatma Gandhi exemplified transformational leadership. Other well known leaders like Mother Teresa and Martin Luther King Jr. also personified 
transformational qualities (Goeglein \& Hall, 2001, cited in Punj \& Krishnan, 2006). Some have made similar comparisons with Sir Apirana Ngata and Te Kooti Arikirangi, both of whom were historical examples of great Māori leaders who engaged in transformational leadership in the Aotearoa setting. Most of the literature around transformational leadership used here comes from business, education, management, and psychology paradigms. But as Burns' (1978) application of transformational leadership theory to Gandhi shows, these theories are adaptable and relevant to discussions around leadership in multiple historical and social contexts.

Transformational leaders construct the vision, while empowering their followers to hold fast to a 'body of ideals' (Bass, 1981, cited in Grint, 1995; Burns, 1978; Grint, 1995). Links can be drawn between charismatic transformational leaders and their followers' levels of self-efficacy (House \& Shamir, 1993; Shamir, House \& Arthur, 1993), or in other words, the followers' beliefs in their collective abilities to enact the leader's vision (Dirks \& Ferrin, 2002; Jung \& Sosik, 2002; Podsakoff, McKenzie, Moorman \& Fetter, 1990). A powerful example of $\mathrm{Te}$ Kooti's influential charisma as a transformational leader is given by the historian James Belich (1986):

Te Kooti was not a chief, he had no tribal basis of support, and his mana did not depend on military success. Yet his authority over his followers was very great - indeed it was more absolute than that of any Maori leader before or after him. The loyalty of his followers was virtually immutable, he was able to gain fresh adherents readily, and his resistance acquired an enormous resilience - again and again, Te Kooti rose phoenix-like from the ashes... [he] was able to control a group of powerful and independent-minded lieutenants, some of whom had far greater hereditary mana than their leader [,]... through what is sometimes called 'charisma' (p. 218-19). 
The followers' self-efficacy informs their thinking, feelings and behaviours (Bandura, 1997). Therefore if they are inspired by their leader, and have an adamant belief in the vision, transformation can be the result (Bottum \& Lenz, 1998; Clawson, 1999; Field \& Van Seters, 1988). In Te Kooti's case, the fact that some of his followers 'outranked' him genealogically did not inhibit his ability to inspire them to follow him (Belich, 1986).

Transformational leaders need to be 'forward-facing' and committed to 'renewal' (Bhindi \& Duignan, 1996, cited in Preece, 2003), but they must also 'look back' to engage with the narratives and histories which tie a community together, and through this activity, create new stories and interpretations (Karpiak, 2000; Preece, 2003). To do this they must know the social, political, spiritual, and geographical landscapes of the people (Karpiak, 2000; Preece, 2003), and "[b]y using the strategies of visioning... transformational leaders... motivat[e] group members to remain attracted to the group, make personal sacrifices and work towards a common goal" (Pillai \& Williams, 2004, p. 147). Hence, if the leader's vision is internalised by the followers, they become dedicated to the collective interests of the group and to achieving the objectives set by the leader (Ackoff, 1999; Avolio, Waldman \& Einstein, 1988; Bass, 1990; Bennis, 1989; Hunt, 1991; Keely, 1995; Keller, 1995; Miles, 1997; Morris \& Staggenborg, 2004; Pillai \& Williams, 2004; Sosik, 1997; Yukl, 1998).

The effects of Te Kooti's transformational leadership can be seen in his Te Umutaoroa vision, which is so well entrenched in the psyche of Patuheuheu and Ngāti Haka, that their goals for restoration through the Treaty of Waitangi settlement process have been underpinned and motivated by it. However, when it was perceived that negotiations to progress the Treaty claims for Tūhoe excluded Patuheuheu and Ngāti Haka, the result was the mobilisation of the Te Umutaoroa social and political movement. Thus the vision was given by Te Kooti, internalised into the hearts and minds of the people, 
transferred down through the generations, adapted to suit the needs of the people in various contexts when required, and finally, it became the philosophical basis for a political movement from October 2008 to the present, as Patuheuheu and Ngāti Haka continue to hold faith in Te Kooti's promise to them.

\section{Prophecy at Te Houhi: transferring the vision}

According to Armin Geertz (1994) (referring to Hopi Indian religion) prophecy is a clan based discourse which materialises as song, myth or speech. Susan Neylan (2002) states that prophecy is a cognitive strategy employed to understand spiritual and paradigmatic shifts, as First Nations people merge introduced Christian ideas with Indigenous spirituality. In Te Kooti's formation and development of the Ringatū movement, a scripturally based religion which synthesised biblical and Māori concepts (Binney, 1988, 1997; Belich, 1986; Elsmore, 1999; 2000; Ross, 1966; Ross, 1966, cited in Walker, 1990), he too melded introduced conceptualisations with Indigenous ones, while using his utterance of prophecies to make sense of current realities. Similarly, Te Umutaoroa became both a commentary on the reality of land loss at Te Houhi, and a clan based prophecy which embodied Patuheuheu and Ngāti Haka's hope for things to come.

Prophecy is described as the receiving of or seeking out of messages from the Gods, God, the ancestors, the articulation of 'special discourses' (Adrahtas, 2007; see also Aune, 1983; Westermann, 1967), and the "...creative elaboration of metaphor with explicit rhetorical consequences for mood and motivation..." (Csordas, 1990, p. 30). Referring to Indigenous Australian prophecies as 'modes of praxis', Adrahtas (2007) states that prophecy must be conceptualised as any “...identification with a given Dreaming that becomes the focal point for the negotiation of collective or community identity" (p. 15). In light of this, Te Umutaoroa gave the people 'mood 
and motivation' to carry on after their land loss, as well as binding the community together to work toward the fulfilment of Te Kooti's vision.

Cruickshank (1994) argues that prophecy is a type of "inversion of myth" (p. 149) which arises when dysfunctional social organisations are unable to explain tumultuous and disruptive events, like wrongful land loss, which in turn cause the people to look beyond their past and present towards the future. In reference to Max Weber's (1922) analysis of Old Testament prophets, Cruikshank (1994) insists that prophets appear "outside routine institutional order to contest the social and political authority of established leaders" (p. 149). However, Weber's (1922) analysis argues that prophets as 'outsiders' rise up to challenge the status quo but 'fail to transform' the social and political context(s). This analysis is problematised by Te Umutaoroa (Binney, 2001a), since Te Kooti arose from the margins like a Phoenix from the proverbial ashes, to challenge the power structures of the status quo (Belich, 1986). While Judith Binney (1995, 2001a) maintains that $\mathrm{Te}$ Kooti literally and metaphorically 'transformed' an awful situation of land loss and betrayal by "erasing the poison of fraud with a quest for a renewal of life" (Binney, 2001a, p. 148). Furthermore, Cruikshank (1994) argues that Subarctic Aboriginals, for example, do not view prophecy in terms of 'failure', as Weber does, but as "successful engagement with change and detailed foreknowledge of events" (p. 149), which describes what Te Kooti did.

As a prophecy, Te Umutaoroa symbolises hope and is a means through which the history of Te Houhi is remembered. According to Margaret Kovach:

Stories are vessels for passing along teachings, medicines, and practices that can assist members of the collective. They promote social cohesion... (Kovach, 2009, p. 95). 
In this way, Te Umutaoroa transports the story of the Waiohau Fraud through to each successive generation, and encourages the uniting of hearts and minds in multiple sites of struggle, including the ideological, political, social, economic and cultural. For example, Robert Pouwhare (2004) talks about Te Umutaoroa as a narrative passed down through the generations, and as an inspiring emblem for the return of Patuheuheu and Ngāti Haka's land:

For us Te Umutaoroa is a symbol for all land lost. We wait now for the fulfilment of Te Kooti's dream - that our land may one day be returned.

These stories we teach future generations so that these prophecies of Te Koot[i] will never die. We try to [in]still in our grandchildren the truth to seek the right path so that our lands are returned and all the resources stolen from us by tauiwi and the Native Land Court and the fraudsters be returned to us (p. 40).

Additionally, in a submission to the Waitangi Tribunal, Robert Pouwhare (2004) states: "I value education, teaching and schooling. I believe that if our youth are armed with education and qualification[s] the world is theirs" (p. 27). His assertion echoes the words of Freire and Macedo (1987): 'read the word, read the world'. It can be concluded that the 'right path' that Pouwhare refers to for the youth of Patuheuheu and Ngāti Haka is education, for with education they will be able to work towards the emancipation of their people, and the return of lands and resources, and thus the fulfilment of Te Kooti's prophecy. Pouwhare (2004) states:

We have in our possession the legacy of $\mathrm{Te}$ Umutaoroa. The histories were left with our rangatira Hieke Tupe. Out of the discourse of Te Umutaoroa emerges a clear picture of Harry Burt's fraud. Te Umutaoroa grew out of the betrayal by Harry Burt of Te Kooti and the betrayal of Ngati Haka - Patuheuheu. Te Kooti left Te Umutaoroa at Te Houhi and it is said that 
that is the payment of the sins of Harry Burt - that which is contained in Te Umutaoroa - it is said Te Kooti's chosen child will one day come to uncover the hangi of Te Umutaoroa - the earth oven of long cooking (p. 38).

It is evident that the vision of Te Umutaoroa is transferred through the whakapapa of Patuheuheu and Ngāti Haka, and that it is kept alive through a process of storying. It is also clear from Pouwhare's statements that education is considered an important part of facilitating the realisation of $\mathrm{Te}$ Umutaoroa.

\section{Contemporary interpretations of the principles of Te Umutaoroa}

The following are interpretations of the mauri of $\mathrm{Te}$ Umutaoroa as the author sees them at this point in time, within the context of this academic text, and in terms of the author's future ambition to formulate a framework for Patuheuheu and Ngāti Haka unity, development and transformation. Thus, the author offers these interpretations as a means to work towards a model, with the expectation that the author, and others from Patuheuheu and Ngāti Haka, will continue to develop frameworks based on Te Umutaoroa with which to inform the future in a variety of settings. Some of the author's interpretations are broader, and others are focussed more on transformation through education, but all are a beginning of a framework for Patuheuheu and Ngāti Haka development going forward.

\section{Te Mauri Atua}

Te Mauri Atua is essentially about whakapapa, knowledge, and spiritual practices. It is the genealogical interconnectivity of Patuheuheu and Ngāti Haka (as Māori) to multiple layers of reality, to the Gods, to Papatūānuku - earth mother and Ranginui - sky father, to each other, and to the environment, in a framework of collective consciousness (see Aranga, 2005; 
Barlow, 1991; Durie, 1998; Kereopa in Moon, 2003; Salmond, 1985). Mason Durie's (1998) 'Mana Atua' concept relates here:

Māori views of the world are based on the proposition that the environment is an interacting network of related elements, each having a relationship to the others and to earlier common origins [of the creation of the universe]. The personification of the earth and the sky as the parents Rangi and Papa underlines that point. Not only as a distinctly human dilemma presented as an explanation for creation, but by comparing the features of the environment to a family, a model is proposed for examining the connections and interdependencies which occur between forests and oceans, fish and fowls, the rivers and the soil and between people and the elements ( $\mathrm{p}$. 21-2).

This principle is therefore about unity in terms of realising the interrelating nature of whakapapa to physical, spiritual, cosmological, and epistemological realities, and in terms of transformation, this principle is pivotal, as negotiating respectful relationships between these realms and realities is necessary to bring about positive change. Transformation can be achieved in part through karakia, which permits access to 'inward knowledge', and also to traverse 'sacred space'. Margaret Kovach (2009) gives an Indigenous example:

From a[n Indigenous] Nêhiýaw epistemology, attention to inward knowledge is not optional. From a traditional Cree perspective, seeking out Elders, attending to holistic epistemologies, and participating in cultural catalyst activities (dream, ceremony, prayer) are all means for accessing inward knowledge (Kovach, 2009, p. 50).

In metaphysical and philosophical terms, Indigenous knowledge and scholarship, as 'sacred energy' (Cajete, 1999; Cardinal \& Hildebrandt, 2000; Little Bear, 2000), reveals itself 
as 'knowings' contained within an interconnected framework of consciousness, released through rituals, prayer, dreams and cultural phenomenon (Cardinal, 2001). Indigenous cultural and spiritual practices therefore open passages of knowledge to be accessed and developed. Thus, from a Māori perspective, the utterance of karakia, which have their own impactful mauri or life force (Kereopa in Moon, 2003), is imperative, as it facilitates the release of knowledge from collective consciousness, and from a Patuheuheu and Ngāti Haka perspective, karakia and other spiritual and cultural customs are totally obligatory in every facet of hapu life.

The constituents of the Māori world are so closely intertwined and interdependent, that it is absolutely fundamental to acknowledge these links and relationships through cultural processes such as karakia, by recognising that one's movements and actions have an effect on the mauri or life essence of people and places and vice versa:

...all living things, including natural and physical resources, possess a mauri, a life principle or life essence. [Animate and inanimate objects are]...afforded a spiritual existence which complements the physical state. Nothing is lifeless. Damage to a resource not only creates physical impairment but also causes spiritual damage and in the process impinges on the mauri of other objects [animate and inanimate], including people (Durie, 1998, p. 23).

Therefore, in a Patuheuheu and Ngāti Haka milieu, it is necessary to acknowledge the whakapapa, genealogical, social, cultural, psychological and historical links of the people to places, spaces, stories, and geographical and spiritual landscapes. It is the view of the author that Te Mauri Atua is the 'key' to all of the other life principles of Te Umutaoroa, because it provides the cosmological and epistemological starting point for all things. 


\section{Te Mauri Whenua}

Te Mauri Whenua is about respecting the life force of the land, and in turn acknowledges the interconnectivity of land, environment and people. Whenua is connected through whakapapa to human beings and is a pivotal part of identity (Cheater \& Hopa, 1997; Durie, 1998; L. Smith, 1999a). The term 'whenua' is located within a Māori conceptual framework as a living and breathing entity, and is in direct opposition to the commodified notion of 'land' as soil, terra firma, and property in Western thinking (Mika, 2005).

Te Mauri Whenua acknowledges Patuheuheu and Ngāti Haka as kaitiaki of the whenua as a "...taonga for future generations" (Durie, 1998, p. 23). It is about respecting the sacred aspects of whenua - such as urupā, waahi tapu, maunga, and other areas of significance - and should serve to remind Patuheuheu and Ngāti Haka to 'tread carefully' and respectfully. This principle acknowledges that "Land is necessary for spiritual growth and economic survival" (Durie, 1998, p. 114) and that despite changes in 'ownership', whenua is intimately connected to the lives and deaths of the people "...for whom it has been home, or for whom it should have been home" (Durie, 1998, p. 115). For Patuheuheu and Ngāti Haka, Te Houhi should have been their home, but even without a physical presence at Te Houhi, Patuheuheu and Ngāti Haka's spiritual and historical connections remain intact forever. While in economic terms, the loss of the land has had a devastating effect on Patuheuheu and Ngāti Haka, the hope they have for the return of their lands and resources, motivates their engagement in multiple sites of struggle today.

\section{Te Mauri Tangata}

Te Mauri Tangata recognises the life force and potential within the people of Patuheuheu and Ngāti Haka. This means 
that Patuheuheu and Ngāti Haka must respect each other as unique identities - subject to differing versions of history which live together and operate as 'one people'. It is about looking for similarities between Patuheuheu and Ngāti Haka, rather than differences, and about uniting as one in the realisation of who the real 'enemies' are - the Crown perhaps? In this sense, Patuheuheu and Ngāti Haka unity can be represented in the cultural notion of eating together. When the hāngi of Te Umutaoroa is unearthed, a 'hākari' will occur, where Patuheuheu and Ngāti Haka will symbolically 'feast' with one another. This offers an alternative view to the divisions caused by past arguments around the mana of Patuheuheu and Ngāti Haka as separate hapū, which have in some cases been espoused uncritically and transferred hegemonically through successive generations. Some of these arguments are unproductive and cause division, and so Te Umutaoroa offers a way to unify Patuheuheu and Ngāti Haka through the collective history they share from the loss of $\mathrm{Te}$ Houhi. Imperatively, this principle is also about showing respect to other people from outside of Waiohau, ensuring that reciprocity, generosity, manaakitanga and matemateāone is shown.

As Māori, Patuheuheu and Ngāti Haka are subjected to social and economic problems which have resulted from a history of loss and oppression. However, within whānau and hapu structures, their ability to improve these circumstances can be increased through their collective efforts working together. Te Kooti's narrative was presented to the whānau of Patuheuheu and Ngāti Haka, passed from one generation to the next, and exists within this hapū-whānau network today, being constantly and adaptively reinterpreted and metamorphosised according to the needs of the day.

\section{Te Mauri Whakapono}

Te Mauri Whakapono is literally a principle about faith and truth. It is about holding on to hope, not giving up, and 
engaging in constant struggle towards better outcomes. Te Mauri Whakapono, from the author's perspective, is the driving force behind Te Kooti's vision for Patuheuheu and Ngāti Haka. The power of belief and the confidence in Te Kooti's words is what gives Patuheuheu and Ngāti Haka their drive to move forward. This mauri is also about being true to one's self, to one's values, to one's people, and to the kaupapa. Te Kooti's prophetic narrative provides the blueprint or the kaupapa for change. His vision literally supplies the elements for a revolutionary curriculum of positive change for Patuheuheu and Ngāti Haka. In this sense, Te Umutaoroa is a charter between the people and their prophet, which provided the people of Te Houhi with relief from a desperate situation, and which continues to inspire and give hope for an improved future, imparting the motivation to work towards transformation in the present.

\section{Te Mauri Whakaora i nga Iwi}

Te Mauri Whakaora i nga Iwi is about healing the people of Patuheuheu and Ngāti Haka in terms of historical injustices, and breaking free from the perpetual cycle of social, political and economic oppression. This principle correlates with the Freirean idea of 'becoming more fully human', or in other words the process of transformative praxis: conscientisation, resistance and transformative action (Freire, 1972). This is about educational, social and economic, and political transformation for Patuheuheu and Ngāti Haka. As Paulo Freire (1970) states: "It is absolutely essential that the oppressed participate in the revolutionary process with an increasingly critical awareness of their role as subjects of the transformation" (p. 127). Therefore, Patuheuheu and Ngāti Haka conscientisation through theory, research and education:

...must be a critical attempt to reveal reality... It must, that is, be related to political involvement. There is no conscientization if the result is not the conscious 
action of the oppressed as an exploited social class, struggling for liberation (Freire, 1985, p. 125).

Leonie Pihama (2004) maintains that Māori do not have time to theorise for theory's sake, or philosophise for philosophy's sake; Māori have lost too much that needs to be reclaimed and restored which means that research and theory for Māori must be useful, and must make a real difference, contributing towards a revolutionary cause. Therefore from a Patuheuheu and Ngāti Haka perspective, theory and research should be geared towards positive change for Patuheuheu and Ngāti Haka. It is the author's hope that his research will make these sorts of useful contributions.

\section{Te Mauri Hōhonu}

Te Mauri Hohonu speaks of hidden or underground wealth like diamonds, gold, and minerals, assets generally considered valuable by the West. This notion of hidden wealth, in the view of the author, as it relates to Patuheuheu and Ngāti Haka transformation, is about accessibility to resources and knowledge within the Pākeha world: to penetrate the fortress of the 'gate keeper' and achieve liberation from oppression. This hidden wealth can be activated and engaged with through 'true' conscientised education. Te Mauri Hohonu connects to the power that education has, in terms of the subsequent wealth that can follow as a result, to alleviate the hardships Patuheuheu and Ngāti Haka face. But this mauri equally connects to the whenua in terms of the geological properties hidden beneath the upper layers of the land, in the form of minerals, precious metals, geothermal energy, and other resources.

\section{Te Mauri arai atu i nga Pakanga}

Te Mauri arai atu i nga Pakanga is on one level about "the power to return war from this land to other countries" (Tupe, 
1999, cited in Binney, 2001a, p. 158). The concept of 'war', as interpreted here, is a metaphor for physical, symbolic and ideological conflicts with (neo)colonisation and Western paradigms. This principle is essentially about de-colonisation in terms of realising what parts of the Western culture are appropriate for Patuheuheu and Ngāti Haka, and which parts are not. It is about becoming conscientised or in other words, being conscious and aware of the nature oppression, and the political, economic and social barriers which prevent Patuheuheu and Ngāti Haka development.

Patuheuheu and Ngāti Haka must have autonomy over their own lives, and again, education is important here. Being conscious of oppression and hegemony is an essential 'weapon' in the war against the subordination of Māori language, culture and values, as well as addressing the political and economic structural impediments which prevent Māori/Patuheuheu and Ngāti Haka development. Te Mauri arai atu i nga Pakanga is about resistance and 'warfare,' and today, war is often fought with the voice and with the pen, in politics, media, academia, and in many other ways. Hence, education is required to 'do battle' in these arenas.

\section{Te Mauri Whakahoki i nga Iwi}

Te Mauri Whakahoki i nga Iwi is about returning the people to the land. This notion has provided Patuheuheu and Ngāti Haka with the impetus to continue to resist injustice, and work toward fulfilling the discourse of Te Umutaoroa for the restoration of their lost lands and resources. The Treaty of Waitangi relates here in terms of the Treaty settlement process and the facilitation of the return of land and resources and/or compensation for losses. Although the settlement process is imperfect, and the settlements rather miniscule compared to the actual losses endured, it has the potential to restore a fraction of the dignity which was taken away in the past. While the financial benefits gained, albeit limited, have the potential 
to be used to improve the socio-economic positioning of Māori.

\section{Looking into the Future for Patuheuheu and Ngāti Haka}

This article has argued that $\mathrm{Te}$ Kooti was a transformational leader who instilled in his followers the drive to achieve his vision: to open the cooking pit of Te Umutaoroa, and to harness the power contained therein. This work has suggested that through the uniting of Patuheuheu and Ngāti Haka in their efforts to enact Te Kooti's vision, transformation - which is much more than just 'change', but is "...an enhancement of personal reality, as well as a conversion of reality" (Apps, 1994, p. 211) - will be achieved.

For the development and growth of Patuheuheu and Ngāti Haka, they must move forward as a unified force, if the potential of Te Kooti's prophecy is to be realised. The eight potentials contained within the figurative cooking pit are symbolic of restoration and (re)generation, and also transformation from a history of loss and betrayal, to the 'dawn of a new day', where Patuheuheu and Ngāti Haka can unite to fight injustice head-on and together as 'one people', and move from 'subsistence' to 'sustenance' as promised by Te Umutaoroa. This article has offered some interpretations of the eight mauri, but proposes that these have the potential to be developed into a more substantial model in the future.

Derived from the metaphoricity and propheticism of $\mathrm{Te}$ Kooti's words, and the historic and geographic locality of Patuheuheu and Ngāti Haka, Te Umutaoroa has been used here to express a form of Patuheuheu and Ngāti Haka 'theory'. In this context, $\mathrm{Te}$ Umutaoroa potentially provides the principles or 'bones' of hapu transformation in terms of theory, research and hapū development. According to Judith Binney (2007a):

Te Umutaoroa has become an unfulfilled questnarrative. It is unfulfilled because the land is lost; indeed, it is now drowned beneath the waters of a 
hydro-electric dam, built in 1980. Little islands dot the lake where Te Umutaoroa once was. Once again new meanings are being wrought from this changed landscape (p. 154).

To this day Te Umutaoroa remains unfulfilled. It is however a discourse which is in a constant state of flux, moving and morphing through space and time, from the historical past to the contemporary present, being subjected to discursive modification, to shape the prophecy for the particular contexts within which it is used to inspire and give hope. The 'little islands' which seemingly 'float' on the Aniwhenua lake are emblematic of the mauri stones contained within the now watery cooking pit; they are reminders that the land beneath the water still contains the stories and memories of the past: a past that just 'won't go away'.

Patuheuheu and Ngāti Haka are closely related hapū which share common whakapapa, have intermarried, and have lived together for generations. This has not stopped issues around power and control within the two groupings over the years, the arguments around which may have had some validity 'back then', but are seemingly less transferable now, and ultimately lead to division. Some of the arguments around who has 'more' mana in Waiohau, Patuheuheu or Ngāti Haka, have been problematic in terms of the ruptures which have been created between families and individuals. In a Freirean sense, these contentions are somewhat reminiscent of the oppressed becoming the oppressor (Freire, 1972), and contribute to a system of internal-colonialism within the hapū, which episodically inflames the relationships between the two clans in their tussles for power. These issues can be addressed through the fulfilment of Te Umutoroa.

Patuheuheu and Ngāti Haka share 'blood' and history. They wait together for the fulfilment of Te Umutaoroa, and for the unearthing of the hāngi, from which they will 'feast' together on the 'nourishment' contained within. Te Umutaoroa creates an interlocking network of connections which traverse 
and transcend space and time, embracing the members of the hapu and providing the emphatic drive to move forward, whilst fostering a shared identity formed through loss and the prophetic assurances implied in the promises of the eight mauri. Thus, Te Umutaoroa binds Patuheuheu and Ngāti Haka together, and where there has been in the past, some tension between the two hapū, Te Umutaoroa presents a narrative of unity going into the future, where the 'issues' of the past will be replaced with symbolic and overflowing baskets of 'food', and in consuming this kai, Patuheuheu and Ngāti Haka will be transformed.

Indeed, as Linda Smith (1999) and Anne Salmond (1985) point out, Māori intelligence was/is located in the puku, and therefore, the ingestion of 'food' from Te Umutaoroa will result in a process of praxis which originates in the metaphorical pit of the hāngi, and is then 'processed' in the pit of the human belly, the Māori mind, wherein a process of conscientisation takes place. What emerges from this conscientisation is the knowledge that Patuheuheu and Ngāti Haka, if they are to stand any chance of surviving and developing, must unite and move forward together 'as one'. As Robert Pouwhare (2010, personal communication) states: “...like it or not, we [Patuheuheu and Ngāti Haka] are in this together; we're moving forward, and we're a force to be reckoned with".

\section{Bibliography}

Ackoff, R. L. (1999). Transformational leadership. Strategy \& Leadership, 27(1), 20-25.

Adas, M. (1979). Prophets of rebellion: Millenarian protest movements against the European colonial order. Chapel Hill: The University of North Carolina Press.

Adrahtas, V. (2007). Prolegomena to the history of Indigenous Australian prophetic consciousness. Sydney Studies in Religion. Retrieved February 18, 2010 from http://escholarship.usyd.edu.au/journals/index.php/SSR/article /view/122/143

Apps, J. W. (1994). Leadership for the emerging age. San Francisco: Jossey Bass. 
Alimo-Metcalfe, B. (2001). Transforming leaders. Developing People Newsletter, 45. Retrieved 26 February, 2010 from http://www.roffeypark.com/newletter/dp45winter01/backpage.ht $\mathrm{ml}$.

Aranga, M. (2002). Aspects of mātauranga Māori: A hermeneutic exploration of whakapapa and knowledge. Unpublished master's thesis, Te Whare Wānanga o Awanuiārangi, Whakatāne, New Zealand.

Ardichvili, A. \& Gasparishvili, A. (2001). Leadership profiles of managers in post-communist countries: A comparative study. Leadership and Organization Development Journal, 22(2), 691.

Astin, A. W. \& Astin, H. S. (2000). Leadership reconsidered: Engaging higher education in social change. Kellogg Foundation. Retrieved February 26, 2010 from http://eric.ed.gov/ERICDocs/data/ericdocs2sql/content_storage_ 01/0000019b/80/16/68/5b.pdf.

Aune, E. (1983). Prophecy in early Christianity and the ancient Mediterranean world. Michigan: William B. Eerdmans Publishing.

Avolio, B. J., Walderman, D. A., \& Einsten, W. A. (1988). Transformational leadership in a management game situation. Group and Organizational Studies, 13, 59-80.

Ballara, A. (1998). Iwi: The dynamics of Mãori tribal organisation from c. 1769 to c. 1945 . Wellington: Victoria University Press.

Bandura, A. (1986). Social foundations of thought and action: A social cognitive view. Englewood Cliffs, New Jersey: Prentice Hall.

Bandura, A. (1997). Exercise of personal and collective efficacy in changing societies. In A. Bandura (Ed.), Self-efficacy in changing societies (pp. 1-45). Cambridge: Cambridge University Press.

Barbuto, J. E. \& Burbach, M. E. (2006). The emotional intelligence of transformational leaders: A field study of elected officials. The Journal of Social Psychology, 14(1), 51-64. Retrieved February 26, 2010 from

http://www.icti.ie/articles/The\%20EI\%20of\%20Transformational\%201 eaders $\% 20 A \% 20$ field $\% 20$ study $\% 20$ of $\% 20$ elected $\% 20$ officials.pdf.

Barlow, C. (1991). Tikanga whakaaro: Key concepts in Mãori culture. South Melbourne: Oxford University Press.

Bass, B. M. (1985). Leadership and performance beyond expectations. New York: The Free Press.

Bass, B. M. (1990). Bass and Stogdill's handbook of leadership: Theory, research, and managerial applications. New York: The Free Press.

Bass, B. M. \& Avolio, B. J. (1990). Developing transformational leadership: 1992 and beyond. Journal of European Industrial Training, 14, 21-27.

Bass, B. M. \& Avolio, B. J. (1994). Improving organizational effectiveness through transformational leadership. Thousand Oaks, California: Sage Publications.

Belich, J. (1986). The New Zealand wars. Auckland: Penguin. 
Belich, J. (1988). The New Zealand wars and the Victorian interpretation of racial conflict. Auckland: Penguin Books.

Belich, J. (1996). Making peoples: A history of the New Zealanders from Polynesian settlement to the end of the nineteenth century. Auckland: Penguin Books.

Belich, J. (2001). Paradise forged: A history of the New Zealanders from the 1880s to the year 2000. Auckland: Penguin Books.

Belich, J. (2001). Myth, race, and identity in New Zealand. In J. Binney (Ed.). The shaping of history: Essays from the New Zealand Journal of History (pp. 356-66). Wellington: Bridget Williams Books.

Belich, J. (2009). Riders in the whirlwind: Tribal peoples and European settlement booms, 1790s-1900s. In R. Boast \& R. S. Hill (Eds.), Raupatu: The confiscation of Maori land (pp. 33-27). Wellington: Victoria University Press.

Bennis, W. (1989). On becoming a leader. Reading, Massachusetts: Addison-Wesley Publishing.

Bensimon, E. (1989). Transactional, transformational and "transvigorational" leaders. World Wide Web Edition of Leadership Abstracts, 2(6). Retrieved February 27, 2010 from http://www.league.org/publications/abstracts/leadership/labs04 89.html

Best, E. (1925). Tuhoe: children of the mist. Auckland: Reed Publishing (NZ) Limited.

Binney, J. (1988). The Ringatu traditions of predictive history. The Journal of Pacific History 23(2), 167-174.

Binney, J. (1997). Redemption songs: A life of Te Kooti Arikirangi Te Turuki. Auckland, New

Zealand: University Press and Bridget Williams Books.

Binney, J. (2001a). Te Umutaoroa: The earth oven of long cooking. In A. Sharp \& P. McHugh (Eds.), Histories, power and loss: Uses of the past - a New Zealand commentary (pp. 146-64). Wellington, New Zealand: Bridget Williams Books Limited.

Binney, J. (Ed.). (2001b). The shaping of history: Essays from the New Zealand Journal of History. Wellington: Bridget Williams Books.

Binney, J. (2002). Encircled lands, part one: A history of the Urewera from European contact until 1878. An overview report on the Urewera (Wai 894 \# A15). Report to the Waitangi Tribunal, Wellington, New Zealand.

Binney, J. (2003). Statement of Judith Binney in response to questions of clarification. Wai 894. Submission to the Waitangi Tribunal, Wellington, New Zealand.

Binney, J. (2007a). When the white kawau flies. In J. Lutz (Ed.), Myth and memory: Stories of Indigenous-European contact (140-159). Vancouver: UBC Press.

Binney, J. (2007b). Te Kooti Arikirangi Te Turuki ? - 1893. In Dictionary of New Zealand Biography, updated 22 June 2007. Retrieved August 25, 2009 from 
http:/ / www.dnzb.govt.nz/DNZB/alt_essayBody.asp?essayID=1T4 5.

Binney, J. (2008). Te Kooti Arikirangi Te Turuki, c. 1832-17 April 1893. Kōtare, 7(2), 39-47.

Binney, J. (2009a). Encircled lands: Te Urewera, 1820-1921.

Wellington: Bridget Williams Books.

Binney, J. (2009b). Te upokokohua: The curse of confiscation on Te Urewera. In R. Boast \& R. S. Hill (Eds.), Raupatu:The confiscation of Maori land (pp. 222-32). Wellington: Victoria University Press.

Binney, J., Bassett, J. \& Olssen, E. (1990). The people and the land: An illustrated history of New Zealand 1820-1920. Wellington: Allen $\&$ Unwin New Zealand Limited \& Port Nicholson Press.

Binney, J., Chaplain, G., \& Wallace, C. (1979). Mihaia:The prophet Rua Kenana and his community at Maungapohatu. Auckland: Auckland University Press.

Bottum, B. \& Lenz, D. (1998). Within our reach: Servant leadership for the twenty-

first century. In Spears, L. C. (Ed.), Insights on leadership service, stewardship, spirit, and servant leadership (pp. 157-169). New York: John Wiley \& Sons.

Burns, E. B. (1977). Latin America: A concise interpretive history. New Jersey: Prentice Hall.

Burns, J. M. (1978). Leadership. New York: Harper \& Row Publishers.

Cajete, G. (1999). Native science: Natural laws of interdependence. Santa Fe: Clear Light Publishers.

Cardinal, L. (2001). What is an Indigenous perspective? Canadian Journal of Native Education, 25(2), 180-2.

Cardinal, H. \& Hildebrandt, L. (2000). Treaty Elders of Saskatchewan: Our dream is that our peoples will one day be clearly recognized as nations. Calgary: University of Calgary Press.

Cheater, A. \& Hopa, N. (1997). Representing identity. In A. James, J. Hockey \& A. Dawson (Eds.), After writing culture: Epistemology and praxis in contemporary anthropology (pp. 208-23). Oxon: Routledge.

Clawson, J. G. (1999). Level three leadership: Getting below the surface. Upper

Saddle River, New Jersey: Prentice-Hall.

Covey, S. (2001). Transformational vs. Transactional leadership.

Retrieved 26 February, 2010 from

http://www.sportscareers.com/insiders/archived_articles/archive dDetails.asp?id=104.

Cruickshank, J. (1994). Claiming legitimacy: Prophecy narratives from Northern Aboriginal Women. American Indian Quarterly, 18(2), 147-167.

Csordas, T. J. (1990). Embodiment as a paradigm for Anthropology. Ethos, 18(1), 5-47.

Deloria, V., Jr. (2002). Evolution, creationism, and other modern myths: A critical inquiry. Golden, Colorado: Fulcrum. 
Dirks, K. T. \& Ferrin, D. L. (2002). Trust in leadership: meta-analytic findings and implications for research and practice. Journal of Applied Psychology, 87(4), 611-28.

Doherty, W. (1995). Traditional history relating to Matahina $C \& C 1 \&$ Patuheuheu and Ngati Haka. Te Runanganui o Te Ika Whenua WAI 212.

Durie, M. (1998). Te mana, te kāwanatanga:The politics of Mãori selfdetermination. South Melbourne, Australia: Oxford University Press.

Durie, M. (2003). The Parameters of Māori Development. In Contesting Development: Pathways to Better Practice, 5-7 November 2002 (pp. 141-147).Massey University, Palmerston North, New Zealand:

Aotearoa New Zealand International Development Studies Network (DevNet). Retrieved September 17, 2009 from http://www.devnet.org.nz/conf2002/papers/Durie_Mason.pdf.

Durie, M. (2005). Ngā tai matatū: Tides of Māori endurance. Melbourne: Oxford University Press.

Durie, M. (2009). Maori knowledge and medical science: The interface between psychiatry and traditional healing in New Zealand. In M. Incayawar, R. Wintrob, L. Bouchard \& G. Bartocci (Eds.), Psychiatrists and traditional healers:Unwitting partners in global mental health (237-49). Chichester, West Sussex, UK: John Wiley $\&$ Sons Limited.

Eketone, A. (2008). Theoretical underpinnings of Kaupapa Māori directed practice. MAI Review, 1, Target Article. Retrieved August 20, 2009 from http://ojs.review.mai.ac.nz/index.php/MR/article/view/98/106.

Elsmore, B. (1999). Mana from heaven: A century of Maori prophets in New Zealand. Auckland: Reed Publishing (NZ) Limited.

Elsmore, B. (2000). Like them that dream: The Maori and the old testament. Auckland: Reed Publishing (NZ) Limited.

Field, R. H. G. \& Van Seters, D. A. (1988). Management by expectations (MBE): The power of positive prophecy. Journal of General Management, 14(2), 19-33.

Freire, P. (1972). Pedagogy of the oppressed. Harmondsworth: Penguin.

Freire, P. (1976). A few notions about the word 'conscientization'. In R. Dale, G Esland \& M. McDonald (Eds.), Schooling and capitalism: A sociological reader (pp. 224-27). London: Routledge.

Freire, P. \& Macedo, D. (1987). Literacy: Reading the word and the world. London: Routledge.

Geertz, A. W. (1994). The invention of prophecy: Continuity and meaning in Hopi Indian religion. Los Angeles: University of California Press.

Gist, M. \& Mitchell, T. R. (1992). Self-efficacy: A theoretical analysis of its determinants and malleability. Academy of Management Review, 17(2), 183-211.

Grint, K. (1995). The alchemy of leadership. In K. Grint, Management: A sociological introduction (pp. 124-61). Oxford: Polity Press. 
Gronn, P. (1995). Greatness revisited: The current obsession with transformational leadership. Leading and Managing 1(1), pp. 1427. Retrieved 26 February, 2010 from http://student.edfac.unimelb.edu.au/482-707/fronn_95.html.

Hanson, A. (1990). Christian branches, Maori roots: The cult of Rua. History of Religions 30(2), 154-178.

Henderson, J. Y. (2000). Postcolonial ghost dancing: Diagnosing European colonialism. In M. A. Battiste (Ed.), Reclaiming Indigenous voice and vision (pp. 57-76). Vancouver: UBC Press.

House, R. J. \& Shamir, B. (1993). Toward the integration of transformational, charismatic, and visionary theories. In M. M. Chemers \& R. Ayman, R. (Eds.), Leadership theory and research: Perspectives and directions (pp. 81-103). San Diego, California: Academic Press.

Hunt, J. G. (1991). Leadership: A new synthesis. Newbury Park, California: Sage Publications.

Johnson, W. (1996). Contemporary Native American prophecy in historical perspective. Journal of the American Academy of Religion, 64(3), 575-612.

Jung, D. I. \& Sosik, J. J. (2002). Transformational leadership in work groups: The role of empowerment, cohesiveness, and collectiveefficacy on perceived group performance. Small Group Research, 33(2), 313-36.

Kaplan, J. H. (1908). Psychology of prophecy: A study of the prophetic mind as manifested by the ancient Hebrew prophets. Philadelphia: Julius H. Greenstone.

Karpiak, I. E. (2000). Evolutionary theory and the "new sciences": Rekindling our imagination for transformation. Studies in Continuing Education, 22(1), 29-44.

Keeley, M. (1995). The trouble with transformational leadership: Toward a federalist ethic for organizations. Business Ethics Quarterly, 5(1), 67-96.

Keller, R. T. (1995). Transformational leaders make a difference. Research Technology Management, 38(3), 41-48.

Kirkpatrick, S. A. \& Locke, E.A. (1996). Direct and indirect effects of three core charismatic leadership components on performance and attitudes. Journal of Applied Psychology, 81(1), 36-51.

Kovach, M. (2009). Indigenous methodologies: Characteristics, conversations, and contexts. Toronto: University of Toronto Press.

Lennings, C. J. (1994). An evaluation of a generalized self-efficacy scale. Personality and Individual Differences, 16(5), 745-50.

Liontos, L. B. (1992). Transformational leadership. ERIC Digest, 72. Retrieved February 27, 2010 from http://ericfacility.net/ericdigests/ed347636.html.

Little Bear, L. (2000). Jagged worldviews colliding. In M. Battiste (Ed.). Reclaiming Indigenous voice and vision (pp. 77-85). Vancouver: University of British Columbia Press.

McGregor, S. L. T. (2004). Using transformative leadership and critical science in public policy. In C. Anderson (Ed.), Family and 
community policy (pp. 157-68). Alexandria: American Association of Family and Consumer Affairs. Retrieved 26 February, 2010 from

http:/ / www.consultmcgregor.com/documents/publications/transfor mative-leadership-critical-science-and-public-policy-for-web.pdf.

Mika, C. (2005). When the "Gaze" meets the "gaze": Medical science and its normalisation of the Maori body. Unpublished master's thesis, Te Whare Wānanga o Awanuiārangi, Whakatane, New Zealand.

Mika, C. (2007). The utterance, the body and the law: Seeking an approach to concretizing the sacredness of Maori language. Sites: A Journal for South Pacific Cultural Studies, 4(2) 2007, 181-205.

Miles, R. H. (1997). Leading corporate transformation: A blueprint for business renewal. San Francisco, California: Jossey-Bass Publishers.

Moon, P. (2003). Tohunga: Hohepa Kereopa. Auckland: David Ling Publishing.

Morris, A. D. \& Staggenborg, S. (2001). Leadership in social movements. In D. A. Snow, S. A. Soule \& H. Kriesi, The Blackwell companion to social movements (pp. 171-96). Oxford: Blackwell Publishing.

Neylan, S. (2002). The heavens are changing: Nineteenth-century protestant missions and Tsimshian Christianity. Montreal, Quebec: McGill-Queen's University Press.

Nikora, T. (2004a). Tuhoe and the Rangitaiki. Report for the Waitangi Tribunal.

Nikora, T. R. (2004b). Statement of evidence of Tamaroa Raymond Nikora for third hearing week. 18 March 2004. Submission to the Waitangi Tribunal.

Overholt, T. W. (1974). The ghost dance of 1890 and the nature of the prophetic process. Ethnohistory, 21(1), 37-63.

Paul, G. M. (1995). Te Houhi and Waiohau 1B. Te Runanganui o Te Ika Whenua - WAI 212.

Pihama, L. (Director of Maori and Indigenous Analysis). (2004). Kaupapa Maori theory and research hui [DVD]. New Zealand: Maori and Indigenous Analysis.

Pillai, R. \& Williams, E. A. (2004). Transformational leadership, selfefficacy, group cohesiveness, commitment, and performance. Journal of Organizational Change Management, 17(2), 144-59.

Podsakoff, P. M., MacKenzie, S. B., Moorman, S. B. \& Fetter, R. (1990). Transformational leader behaviours and their effects on followers' trust in leader, satisfaction, and organizational citizenship behaviours. The Leadership Quarterly, 1(2), 107-42.

Pouwhare, R. M. I. (2004). Brief of evidence of Robert Marunui Iki Pouwhare dated the 14th day of March 2004. Wai 894/Wai 726. Submission to the Waitangi Tribunal, Wellington, New Zealand.

Preece, J. (2003). Education for transformative leadership in Southern Africa. Journal of transformative leadership in Southern Africa, 
1(2), pp. 245-63. Retrieved February 26, 2010 from http:/ / eprints.gla.ac.uk/2812/1/transformative_leadership2.pdf.

Punj, A. \& Krishnan, V. R. (2006). Transformational leadership and altruism: Role of power distance in a high power distance culture. Proceedings of the annual conference of the Administrative Sciences Association of Canada, Banff, Alberta, June 2006. Retrieved February 26, 2010 from http://www.rkvenkat.org/ankush.pdf

Rangiwai, B. (2010). The effects of racism on Māori land loss: Colonising discourses for Te Patuheuheu and Ngāti Haka. Unpublished master's thesis, Te Whare Wānanga o Awanuiārangi, Whakatāne, New Zealand.

Ranui, A. M. (2004). Brief of evidence of Alec Mahanga Ranui dated the 14th day of March 2004. Wai 894/ Wai 726. Submission to the Waitangi Tribunal, Wellington, New Zealand.

Ross, W. Hugh. (1966). Te Kooti Rikirangi: General and prophet. Auckland: Collins.

Royal, T. C. (1992). Te haurapa: An introduction to researching tribal histories and traditions. Wellington: Bridget Williams Books \& Historical Branch, Department of Internal Affairs.

Royal, T. C. (Ed.). (2003). The woven universe: Selected writings of Rev Māori Marsden. Masterton: The Estate of Rev. Māori Marsden.

Salmond, A. (1978). Te ao tawhito: A semantic approach to the traditional Maori cosmos. Journal of the Polynesian Society, 87(1), 5-28.

Salmond, A. (1985). Maori epistemologies. In J. Overing (Ed.), Reason and morality (pp. 240-64). London: Routledge.

Salmond, A. (1991). Two worlds: First meetings between Maori and Europeans 1642-1772. Auckland: Viking.

Salmond, A. (1997). Between worlds: Early exchanges between Maori and Europeans 1773-1815. Auckland: Penguin.

Scholl, R. W. (2002). Leadership style. Retrieved February 26, 2010 from http://www.cba.uri.edu/scholl/notes/leadership_approaches.ht $\mathrm{ml}$.

Shamir, B., House, R. J. \& Arthur, M. (1993). The motivational effects of charismatic leadership: A self-concept based theory. Organizational Science, 4(4), 577-94.

Sheppard, G. T. \& Herbrechtsmeier, W. E. (2005). Prophecy. In L. Jones (Ed.), The encyclopedia of religion (pp. 7423-29). New York: Macmillan.

Shields, C. (2003). Good intentions are not enough: transformative leadership for communities of difference. Lanham, Maryland, and Oxford: Scarecrow Press.

Sinclair, K. (2002). Prophetic histories: The people of the Māramatanga. Wellington: Bridget Williams Books Limited.

Smith, L. T. (1999). Decolonizing methodologies. Dunedin: Otago University Press.

Stokes, G. (2003). A call for transformational leadership. Retrieved February 26, 2010 from 
http://www.movethemountain.org/transform_leadership/articles /leadership_assessment.cfm.

Stone, A. G. \& Patterson, K. (2005). The history of leadership focus. Servant Leadership Research Roundtable, School of Leadership Studies, Regent University, August 2005. Retrieved February 26, 2010 from http://www.regentuniversity.org/acad/global/publications/sl_pro ceedings/2005/stone_history.pdf.4006381333627.

Walker, R. (1990). Ka whawhai tonu matou: Struggle without end. Auckland: Penguin Books.

Weber, M. (1922). The sociology of religion. Massachusetts: Beacon Press.

Westermann, C. (1967). Basic forms of prophetic speech. Philadelphia: Westminster Press.

Yukl, G. (1998). Leadership in organizations (4th edition). Englewood, New Jersey: Prentice-Hall. 